21) N. L. Foskett (惠谷), 化工, 21, 741 (1957).

22）小島, 石油学会誌, 3, No. 7570 (1960)。

23) Petrol. Refiner, 36, No. 11 (1957).

24) ibid. 34, No. 12 (1955).

25) F. F. Baraconier (石原) 石油学会誌, 3, 563 (1960).

26) Koppers 社資料, Oct. 29, (1958).

27）東ガス調査室,“油ガス”ダイヤモンド社 (1954).

28) M. O. Klipatrick et al, Petroleum Processing, 9, 903 (1954).

29) World Petrol., 30, June, Sect. II. Germany, 62 (1959).

30) Chem. Eng., 66, Aug. 24, 66 (1959).

31) Erdöl u Kohle, 13, No. 5336 (1960).

32) R. M. Deanesly \& C. H. Watkins, Chem. Eng. Process, 47, 134 (1951).

33）三井物産，化学機技術資料。

34) H. E. Charlton, Oil \& Gas J., 50, No. 33201
(1951).

35）中島, 燃協誌, 39, 399, 502 (1960).

36）宮原, 小沢, 石油学会誌 3, No. 4317 (1960).

37) P. W. Shərwood, Retrol. Refiner, 31, No. 1 126 (1952).

38) A. W. Pratt \& N. L. Foskett, Trans. A.I. C. E., 42, No. 1149 (1946).

39) L. Kniel \& W. Slager. Chem. Eng. Progress, 43, 335 (1947).

40) C. Berg et al, Petrol. Refiner, 28, No. 11 113 (1949).

41) F. J. Selgeys, "The Thermal Cracking of Ethane'Oppau Process" FIAT Final Report 1924 (1947).

42) Chem. Eng. Process, Jan. 53 (1960).

43) H. C. Schutt \& S. B. Zdonik, Oil \& Gas J., Arp. 2, 99 (1956).

\title{
Commercial Manufacture of Olefins from Petroleum
}

by Hajime Takahashi

(Maruzen Oil Co.,)

SYNOPSIS :- The demand of alefins tends to amazingly increase with the development of petrochemical industry in these days.

The author gives an outline of commercial manufacture of olefins by thermal cracking of hydrocarbon and describes the problems of petrochemical industry in Japan.

\section{正 誤 訂 正}

前月号、第39巻. 402 号, 中次のごとく訂正致します。

\begin{tabular}{|c|c|c|c|c|}
\hline & & & 鿁 & 正. \\
\hline 722頁 & 石苟 & 卆性カット & 綜説 & 報文 \\
\hline$"$ & & 14行 & Bravisite & Bravaisite \\
\hline " & & 13 " & Montmovillonite & Montmorillonite \\
\hline 724 & & $5 \%$ & $2 . .33$ & 2.33 \\
\hline $726=$ & 左 & $2=$ & 灰分対の H. I & 灰分対 H. I の \\
\hline 728 & & $11 "$ & 9 炭種中 8 炭禋 & 9 炭種中 7 炭種 \\
\hline 729 " & & $7=$ & ×ーの線 & x一線の \\
\hline " & 左 & $15 "$ & $1.31 \sim 1.4181$ & $1.31 \sim 1.418$ \\
\hline $730 \Rightarrow$ & 左 & $17 \%$ & 場合には & 場合は \\
\hline
\end{tabular}

